\title{
THE IMPLEMENTATION OF POE 2 WE MODEL USING SCIENTIFIC APPROACH IN LINEAR LEARNING IN SENIOR HIGH SCHOOL
}

\author{
Nana \\ Physics Education Program of Teacher Training and Education Faculty \\ Siliwangi University of West Java 46115, Indonesia. \\ Email: nana@unsil.ac.id
}

\begin{abstract}
This research aimed to find out and to analyze the difference between the students receiving learning using scientific approach with $\mathrm{POE}_{2} W E$ model and those receiving $P B L$ learning model, and to find out the model effectiveness of Physical learning in Senior High Schools. The sample of research was the students of Senior High Schools in Ciamis Regency taken randomly (using random sampling technique). The research method employed was comparative study conducted in several schools in Ciamis Regency becoming the model of the 2013 curriculum application in the school year of 2013/2014 in the Linear Movement Material of Tenth Grade. To collect the data, several research instruments were used: pre-test and post-test, student questionnaire, observation on the implementation of $\mathrm{POE}_{2}$ WE model learning and interview to get the teachers' response. The data was analyzed using t-test to see the difference of normalized gain in two groups. The result of research showed that there was a significant difference the students receiving learning using scientific approach with $\mathrm{POE}_{2} W E$ model and those receiving PBL learning model. The data showed that the mean scores of pretest and posttest for the learning using $\mathrm{POE}_{2} W E$ model and the one using $P B L$ model were 42.50 and 29.93, respectively and there was an increase in the mean class learning outcome with $\mathrm{N}$-gain $=0.8$ (high category) for $\mathrm{POE}_{2} \mathrm{WE}$ model and $\mathrm{N}$-gain $=0.5$ (medium category) for PBL model. The effectiveness test obtained Sign value $(2$-tailed) $(0.000)<\alpha(0.05)$ meaning that $\mathrm{POE}_{2} W E$ model was more effective than PBL model.
\end{abstract}

Keywords: Scientific Approach, $\mathrm{POE}_{2}$ WE model, Physics of Senior High School

\section{INTRODUCTION}

The main problem with learning in formal education today is the pupil's lower absorbability thereby the students' learning outcome is still lower. To anticipate such the problem, teacher is required to make innovation in learning process. The innovation includes applying the innovative learning models assumed to be able to improve the quality of learning process and outcome (Suryobroto, 2009). The result of observation conducted on Public Senior High Schools in Ciamis Regency showed that the existing learning model has included such aspects of activity as class discussion and demonstration, despite less optimality.

Scientific learning is the one adopting scientific procedures in constructing knowledge through scientific method. The learning model required is the one enabling the cultivation of scientific thinking competency, the development of "sense of inquiry" and the students" creatively thinking ability (Alfred De Vito, 1989). Learning model needed is the one capable of providing learning ability (Joice \& Weil: 1996), not only the acquisition of a number of knowledge, skill, and attitude, but also more importantly how the knowledge, skill and attitude is acquired by the pupils (Zamroni, $2000 \&$ Semiawan, 1998).

Not only scientific learning considers learning outcome as the end, but it also considers learning process as very important. For that reason, scientific learning emphasizes on process skill. The science process skill improvement-based learning model is the one integrating science process skill into integrated material presentation system (Beyer, 1991). This model 
emphasizes more on the process of searching for knowledge than on transfer of knowledge, in which the pupil is considered as learning subject necessarily to be involved actively in learning process, and teacher is only a facilitator who guide and coordinate the learning activity. The 2013 curriculum using scientific learning consists of 5M: mengamati (observing), menanya (questioning), mencoba (experimenting), menganalisis (associating), and mengkomunikasikan (communicating).

As noted above the POE technique has been used extensively to investigate student understanding of a variety of concepts (Gunstone and White 1981; Kearney and Treagust 2000, 2001; Kearney et al. 2001; Liew 1995; Liew and Treagust 1998; Palmer 1995). As well as helping teachers or researchers to identify student alternative conceptions, POE activities also may serve as an instructional strategy, with a particular teaching/learning sequence (Kearney et al. 2001; Liew and Treagust 1998). White and Gunstone (1992) note that the discussions are a key part of using POE (see also, Searle and Gunstone 1990; Tao and Gunstone 1999).

The Prediction, Observation, Explanation, Elaboration, Write and Evaluation ( $\left.\mathrm{POE}_{2} \mathrm{WE}\right)$ learning model is developed from POEW learning model and physical learning model with constructivistic approach. The $\mathrm{POE}_{2} \mathrm{WE}$ model is the one developed to find out the student's understanding on a concept with constructivist approach. This model constructs knowledge with the processes sequence of predicting the solution of problem, conducting experiment to prove the prediction first, and then explaining the result of experiment obtained in spoken or written form, developing the sample application in daily life, writing down the result of discussion and evaluating the students' conception in spoken and written form.

\section{RESEARCH METHOD}

This research employed a comparative method with nonequivalent control group design using two classes: experiment and control. To obtain the data on these classes, pretest and posttest were given, the difference of which lies on the treatment in learning process: the experiment class employed learning with scientific approach through $\mathrm{POE}_{2} \mathrm{WE}$ model and the control employed PBL model.

Technique of analyzing data statistically with independent-sample $t$ test was also used to process the data in the form of mean pretest and posttest, so that the difference of experiment class from the control one could be found. The statistical test was carried out using SPSS 19. Before it was estimated using t-test, the data was first tested for its normality and homogeneity using Kolmogorov-Smirnov test in SPSS program.

\subsection{The normalization of Gain Score}

The normalization of gain score is the analysis technique to find out the students' learning outcome improvement level. The normalized gain score, according to Meltzer (2002) can be estimated in the following formula:

Notes:

$$
<g>=\frac{\text { posttest score-pretest score }}{\text { maximum score-pretest score }}
$$

$<\mathrm{g}>=$ normalized gain

The interpretation of normalized gain score, according to Hake (1998:1), can be seen in Table 1. 
Table 1. Criteria of Normalized Gain

\begin{tabular}{cc}
\hline$<\mathrm{g}>$ score & Criterion \\
\hline \hline$<\mathrm{g}>\geq 0.7$ & High \\
$0.7><\mathrm{g}>\geq 0.3$ & Medium \\
$<\mathrm{g}><0.3$ & Low \\
\hline
\end{tabular}

\section{RESULT AND DISCUSSION}

\subsection{Data of Effectiveness Test Using t-test}

Table 2. Result of pretest, post-test in experimental and control group

\begin{tabular}{ccccc}
\hline The schools in experiment group & \multicolumn{2}{c}{ Pretest } & \multicolumn{2}{c}{ Posttest } \\
\cline { 2 - 5 } & $\mathrm{t}$-value & $\mathrm{p}$ & $\mathrm{t}$-value & $\mathrm{p}$ \\
\hline SMA Negeri 1 Ciamis & 1.159 & 0.251 & 12.159 & 0.000 \\
SMA Negeri 2 Ciamis & 2.235 & 0.079 & 13.943 & 0.000 \\
SMA Negeri 3 Ciamis & 1.310 & 0.195 & 5.289 & 0.000 \\
SMA Negeri Baregbeg & 3.771 & 0.089 & 10.925 & 0.000 \\
\hline Experiment group integrated into & 2.448 & 0.076 & 11.108 & 0.000 \\
the control one & & & &
\end{tabular}

Considering the data in table 2, it can be concluded that there is no significant difference of pretest scores $(p>0.05)$ between the pupils in experiment group and those in control group. From this result of analysis, it can be concluded that the pupils in both experiment and control groups have equal prior competency level.

Based on the data of analysis result with t-test in table 2, it can be concluded that there is a significant difference of posttests score $(p<0.05)$ between experiment and control groups. So there is a significant difference between the students learning using scientific approach with $\mathrm{POE}_{2} \mathrm{WE}$ model and those with PBL model. The conclusion is that the $\mathrm{POE}_{2} \mathrm{WE}$ model is used effectively to improve the pupils' learning achievement in physics subject in SMA Negeri 1 Ciamis, SMA Negeri 2 Ciamis, SMA Negeri 3 Ciamis and SMA Negeri Baregbeg.

The pretest and posttest scores were then estimated for its learning outcome improvement to find out its effectiveness. The formula used was normalized $\mathrm{N}$-gain. The result of $\mathrm{N}$-gain estimation can be seen completely in table 3 .

Table 3. The improvement result of pretest and posttest scores

\begin{tabular}{cccc}
\hline Groups & Schools & Gain Score & Criteria \\
\hline \multirow{4}{*}{ Experiment } & SMAN 1 Ciamis & 0.9 & High \\
& SMAN 2 Ciamis & 0.9 & High \\
& SMAN 3 Ciamis & 0.7 & High \\
& SMAN Baregbeg & 0.8 & High \\
\hline Control & SMAN Cisaga & 0.5 & Medium \\
\hline
\end{tabular}


Considering the data in table 3 , the mean gain score of 0.8 for control group lies on high criterion. It means that there is a high improvement in the pupils' learning outcome in experiment group and medium improvement in control group.

Data of pretest and posttest score distributed normally and homogeneously was then analyzed using Paired Sample t-test. Considering the calculation, it can be found $t_{\text {statistic }}=-$ 13.923 for experiment class and -15.115 for control class with the probability of $0.000(p<$ 0.05 ), therefore Ho is supported. It shows that there is a difference of learning outcome score for the students between before and after the application of POE2WE model. To find out whether or not the improvement of learning outcome is significantly different between experiment and control groups, the t-test was conducted.

The valid data was obtained from 120 students in experiment class and 30 in control class. The mean score is 42.50 for experiment class and 29.93 for control class. Standard deviation was 12.754 for experiment class and 11.399 for control class. The mean standard error was 1.164 for experiment and 2.081 for control classes.

The $\mathrm{F}$ test would examine the basic assumption of t-test that the variance of both groups is the same. Hypothesis Ho = both groups have the same variance. H1 = both groups have different variance. If sig. $>\alpha$, Ho is supported, but if sig. $<\alpha$, Ho is not supported. Sig. value $(0.627)>\alpha(0.05)$, therefore Ho is supported. So, the two groups have same variance.

The next test used equal variance assumed value, but when in the estimation $\mathrm{Sig}<\alpha$, it would use the data below. The hypothesis $\mathrm{Ho}=\mathrm{POE}_{2} \mathrm{WE}$ model does not affect the mean of test value. $\mathrm{H} 1=\mathrm{POE}_{2} \mathrm{WE}$ model affects the mean test value. If sig. $>\alpha$, Ho is supported. And if $\mathrm{Sig}<\alpha$, Ho is not supported. From table 5, it can be found that t-statistic is large and Sig. value (2-tailed) $(0.000)<\alpha(0.025)$; therefore $\mathrm{H}_{\mathrm{o}}$ is not supported. So, $\mathrm{POE}_{2} \mathrm{WE}$ model affects the mean of test score.

\subsection{Discussion on the effectiveness of $\mathrm{POE}_{2} W E$ learning model}

The students said that the learning procedure in the model developed is easy to follow and to understand. The predicting stage the students make based on the prior competency they have can help the students find their own concept. It is in line with Rahayu et. al. (2003) stating that the pupils can use the knowledge they have to explain a concept. Having predicted, the students designed an experiment to do later in order to prove the truth of prediction the students made.

As such, through observation/practical work activity, the students can find themselves their own concept and under the teacher's guide, the students can correct misconception. It is in line with Costu, et al. (2012) stating that predict, observe, and explain stages help the students understand concept more scientifically through direct observation and presentation on the problem explanation. The students can modify the ideas corresponding to scientific view, and adding new knowledge from discussion and observation. This model can be used to find out the students' understanding on a variety of concepts. The result of discussion was then presented before the class.

The group presentation makes the students expressing bravely the ideas arising from respective members of group that later are expressed in classroom discussion. Ningsih (2012:12) stated that discussion is an interactive face-to-face process in which the students exchange ideas about the problem in the attempt of solving the problem, answering question, increasing knowledge and understanding or making decision. The explanation on discussion result was not conducted not only orally but also in written form to make the students remember and understand the material better. In addition, the students not only conclude the 
result of discussion, but also develop the concept map. Nurjanah (2009: 23) said that out of the whole process, the students can experience the changing concept, either expanding the capability they have had or changing their wrong concept inconsistent with the scholars' concept.

Hake's (1998: 1) criteria showed that the students' learning outcome improvement belongs to medium category. It indicates that the application of $\mathrm{POE}_{2} \mathrm{WE}$ learning model affects the students' learning outcome improvement. Considering the result higher in experiment than that in the control classes, it can be said that in the experiment class, the application of $\mathrm{POE}_{2} \mathrm{WE}$ learning model obtained the students' learning outcome improvement higher than that in control class.

The developed $\mathrm{POE}_{2} \mathrm{WE}$ learning model can practice the students' critical thinking ability. In line with Samosir (2010) in his research stating that the improved concept mastery and critical thinking of the students who receive $\mathrm{POE}_{2} \mathrm{WE}$ learning model significantly better compared those receiving conventional learning. It is because in this model, the students are asked to conduct their own experiment before they conduct experiment/practical work.

The students' critical ability is sharpened not only in predicting stage, but also during experiment designing activity. In addition to the presence of elaboration stage addition constituted the application of concept to daily life, and evaluation, the test of measuring the students' concept understanding. This model development is conducted before the students draw a conclusion on the result of discussion in written form in which the students are asked to develop a concept map in every meeting based on the material discussed. The concept mapping in learning facilitates the students to connect the relevant ideas or concepts and to help the students construct an integrated understanding. Jonassen (1987) in Pannen (2005: 119) stated that concept map is the technique of representing the arrangement or relationship between ideas or concept in an individual's mind.

After the analysis, the learning outcome was then tested using prerequisite test before an advanced test was conducted. The result of analysis on pretest and posttest was then analyzed using Paired Sample t-test. The result shows that Ho was not supported. It indicates that there is a difference of students' learning outcome scores between before and after the application of learning model. It also occurs in experiment class indicating that there is a difference of students' learning outcome scores between before and after the application of $\mathrm{POE}_{2} \mathrm{WE}$ learning model. Considering the result of analysis in cognitive domain, it can be concluded that the cognitive learning outcome of students improved.

The improvement of learning outcome is in line with Raminah (2008). The findings of Raminah's (2008) study showed that the model used could improve the pupils' learning outcome because they could use knowledge they have conducted in explaining concept. The pupils' experience is acquired after they conducted observing stage. In this stage, they examine their previous prediction, the final result of observing stage is then discussed by the pupils thereby they obtain the knowledge directly based on their own experience.

The result obtained shows that the difference of cognitive learning outcome before and after treatment lies in the experiment class obtaining higher score than the control class does. It is because in experiment class, the students can conduct not only experiment/practical work really, but also observation. In the presence of interaction, before obtaining teacher's explanation or confirmation, the students can check themselves whether or not the design of experiment or practical work conducted has been correct, and check the compatibility between the prediction and the actual result obtained from practical works. The presence of 
POE2WE can make the students interested in learning the Physical material and make the learning circumstance not monotonous and boring.

\subsection{Potential development of $\mathrm{POE}_{2} \mathrm{WE}$ learning model}

The $\mathrm{POE}_{2} \mathrm{WE}$ learning model gives the students the opportunity of predicting, expressing ideas, designing experiment, conducting experiment, discussing the result of observation and experiment, writing the result of discussion in their own language thus they will be able to understand better the concept and to mastery the Linear Movement material. $\mathrm{POE}_{2} \mathrm{WE}$ learning model is constructivistic and science essence-oriented in which there are three dimensions in science learning (as product, process, and means of developing scientific attitude).

Through the $\mathrm{POE}_{2} \mathrm{WE}$ model, the students can think critically in predicting the problems the teacher suggests. Before the students predict, they would be given teaching material to provide them the incremental knowledge and insight to equip them in predicting. By predicting, the students are invited to think based on their prior knowledge.

The students are practiced to think critically to prepare their own experimental design. Through observation, the students are invited to conduct observation directly, by conducting experiment. The experiment conducted plays a role in concept reinforcement, because in the presence of direct observation, the learning will be more meaningful. This model makes the students communicate the result of discussion and pour ideas not only orally but also in written form. In addition, the students are told to develop a concept map relevant to practical work conducted and based on the material being discussed. The concept map helps the students connect the relevant concepts.

After the students made classroom presentation and discussion, the teachers gave explanation confirming the answer the students suggested. The teacher's explanation is given not only orally, relating to the material and problem discussed, Linear Movement. It makes the students understand better the material and interested in and enjoying the learning.

In addition, in the application of $\mathrm{POE}_{2} \mathrm{WE}$ model, the students obtain direct observation through scientific work on Linear Movement concept. And in addition to improve cognitive learning outcome of students, the psychomotor and affective learning outcomes also improve because they begin to be accustomed with the application of $\mathrm{POE}_{2} \mathrm{WE}$ model to Physical learning.

The strengths of learning using scientific approach with $\mathrm{POE}_{2} \mathrm{WE}$ model lies in the predict step, in which the teacher presents the problem by giving the pictorial problem in LKS to the students. The learning activity in the observe step is experiment. Then in explain step, the students present the result of group discussion and responded by other groups. Another expansion is found in the teacher who giving explanation or confirmation on a less correct concept, in which the teacher show the video to make the students understand the material better. Before the write step the elaboration step is inserted, the application of linear movement into daily life. In the write step, the students not only draw on a conclusion concerning the result of practical works, but also develop a concept map and practical work report. The conclusion in $\mathrm{POE}_{2} \mathrm{WE}$ model lies in evaluation stage, the test of measuring the concept mastery level the teacher gives to the students. 


\subsection{Syntax and learning activities in $\mathrm{POE}_{2} \mathrm{WE}$ learning model}

Table 4. Learning Activities in $\mathrm{POE}_{2} \mathrm{WE}$ learning model

\begin{tabular}{|c|c|c|}
\hline Phases & Teacher activities & Student activities \\
\hline Prediction & 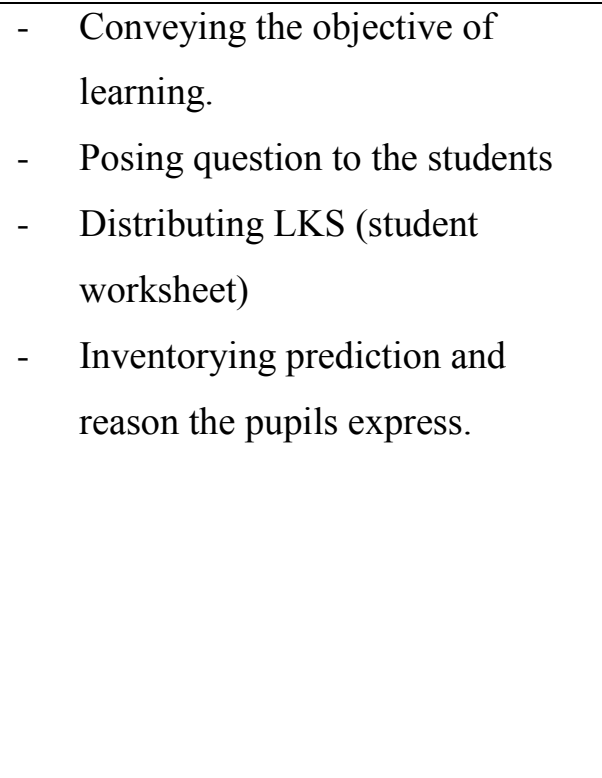 & 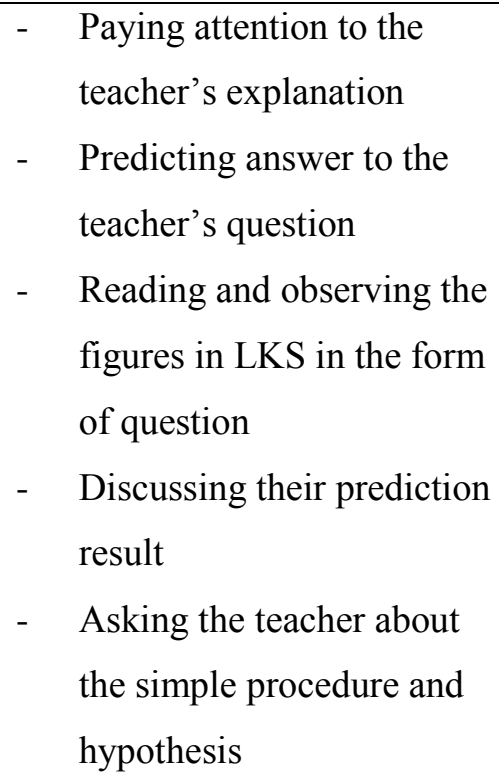 \\
\hline Observation & $\begin{array}{l}\text { - Encouraging the pupils to work } \\
\text { in group } \\
\text { - Overseeing the experiment } \\
\text { activity the pupils undertake }\end{array}$ & $\begin{array}{ll}\text { - } & \text { Creating group } \\
- & \text { Experimenting } \\
- & \text { Collecting data of } \\
& \text { experiment result } \\
- & \text { Discussing in group } \\
- & \text { Inferring the result of } \\
& \text { experiment } \\
- & \text { Analyzing the data of } \\
& \text { experiment }\end{array}$ \\
\hline Explanation & $\begin{array}{l}\text { Encouraging the pupils to } \\
\text { explain the result of experiment } \\
\text { - } \quad \text { Telling the pupils to present their } \\
\text { experiment result } \\
\text { - } \quad \text { Clarifying their experiment result } \\
\text { - } \quad \text { Explaining new concept/idea }\end{array}$ & 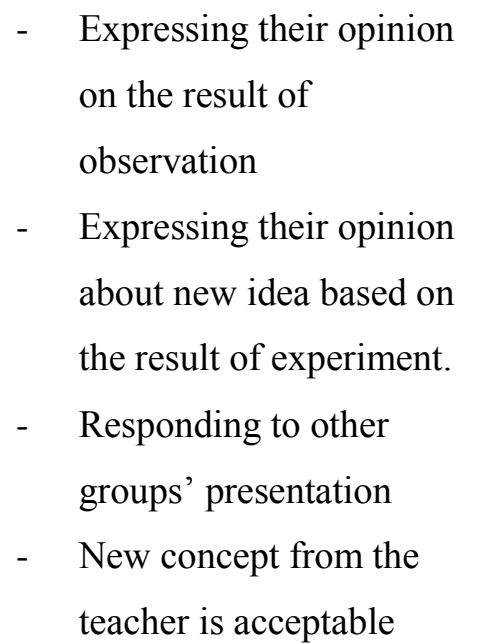 \\
\hline
\end{tabular}




\begin{tabular}{|c|c|c|c|}
\hline Elaboration & - & $\begin{array}{l}\text { Providing the problems relating } \\
\text { to the concept application } \\
\text { Encouraging the pupils to apply } \\
\text { new concept to new situation. }\end{array}$ & $\begin{array}{l}\text { - Applying new concept to } \\
\text { new situation or daily life }\end{array}$ \\
\hline Write & - & $\begin{array}{l}\text { Giving the pupils the opportunity } \\
\text { of recording }\end{array}$ & $\begin{array}{l}\text { Recording the result of } \\
\text { teacher's explanation and } \\
\text { group discussion }\end{array}$ \\
\hline Evaluation & - & $\begin{array}{l}\text { Posing question for process } \\
\text { assessment } \\
\text { Assessing the pupils' knowledge } \\
\text { Giving feedback to the pupils' } \\
\text { answer }\end{array}$ & $\begin{array}{l}\text { - Answering the questions } \\
\text { based on the data } \\
\text { - Demonstrating the concept } \\
\text { mastery ability }\end{array}$ \\
\hline
\end{tabular}

The integration of some stages in POEW learning model into the physical learning model with Constructivistic Approach can be organized in the $\mathrm{POE}_{2} \mathrm{WE}$ learning model below:

a) Prediction

Prediction step is the students make prediction on a problem. The problem found by the teacher derives from question and figure of linear movement existing in LKS (student work sheet)/student book before the students predict. The development of answer prediction in Prediction step in POEW model is identical with Engagement phase in constructivistic approach. The teacher poses a question encouraging the student to make provisional prediction or answer to a problem.

b) Observation

Observation step is to prove the prediction made by the students. The students are invited to experiment relating to the problems encountered. Then, the students observed what occurring, and they examine the correctness of provisional prediction made. Observation step in POEW model is identical with Exploration phase in constructivist approach.

c) Explanation

Explanation step is that the students give explanation on the result of experiment conducted. The students' explanation is given through discussion with the members of group and then individual groups present their discussion result before the class. When the prediction made by the student in fact occurs in the experiment, the student's consultant summarizes and gives explanation to confirm the result of experiment. When the students' prediction does not occur in the experiment, however, the teacher helps the students explain why their prediction is incorrect. The explanation step is identical with the one in constructivistic approach.

d) Elaboration

In elaboration step, the students prepare the example (model) or apply the concept to daily life. Elaboration step is drawn on from constructivistic approach. In this step, the teacher encourages the students to apply new concept to new situation so that they understand better what the teacher teaches. This step is the expansion of constructivistic approach. 
e) Write

Write step is to establish communication in written form, and to reflect on knowledge and idea the students have. Masingilia and Wisniowska (1996) in Ansari (2012), writing can help the students express their knowledge and idea. The students write down the result of discussion and answer the questions existing in LKS. In addition, in this write step, the students draw on a conclusion and write a report on the experiment result. This step is the expansion of TTW model.

f) Evaluation

Evaluation step is the evaluation on students' knowledge, skill and thinking process change. In this stage, the students were evaluated for linear movement material, either in spoken or written form. This stage is the expansion of constructivistic approach. The combination of POEW model's steps and constructivist approach.

\section{CONCLUSION}

Considering the result of research above, it can be concluded that:

There was a significant difference between the students receiving learning using scientific approach with $\mathrm{POE}_{2} \mathrm{WE}$ model and those receiving the one with PBL. The mean score of $\mathrm{N}$ gain was 0.8 for experiment group (high category) and 0.5 for control class (medium category). And the model effectiveness test using t-test obtained $\mathrm{p}<0.05$, meaning that $\mathrm{POE}_{2} \mathrm{WE}$ model was more effective than PBL model.

\section{REFERENCES}

Anderson, Le.W. dan Kreathwohl, D.R. (2001). A Taxonomy For Learning, Teaching, And Assesssing: A Revision of Bloom,s Taxonomy of Educational Objectives. New York. Longman.

Bruner, J. (1996). The Culture of Education. Cambridge, MA: Harvard University Press.

Gunstone, R., \& White, R. (1981). Understanding of gravity. Science Education, 65(3), 291299.

Harding, S. (1998). Is Science Multicultural? Postcolonialisms, Feminisms, and Epistemologies. Bloomington: Indiana University Press.

Huinker, D. Dan Laughlin, C.(1996). Talk Your Way into Writing. In P. C. Elliot, and M. J. Kenny (Eds). Communication in matematics. K-12 and Beyond. USA: NCTM.

Joyce, Bruce. (2009). Models of Teaching. New Jersey : Upper Saddle River.

Kearney, M., \& Treagust, D. F. (2000). An investigation of the classroom use of predictionobservation- explanation computer tasks designed to elicit and promote discussion of students' conceptions of force and motion. Paper presented at the annual meeting of the National Association for Research in Science Teaching, New Orleans, USA.

Kearney, M., \& Treagust, D. F. (2001). Constructivism as a referent in the design and development of a computer program which uses interactive digital video to enhance learning in physics. Australian Journal of Educational Technology, 17(1), 64-79.

Kearney, M., Treagust, D. F., Yeo, S., \& Zadnik, M. G. (2001). Students and teacher perceptions of the use of multimedia supported predict-observe-explain task to probe understanding. Research in Science Education, 31(4), 589-615. 
Kearney, M. (2004) Classroom Use of Multimedia- Support Predict- Observe- Explain Task in a Social Contructivist Learning Environment. Research in Science Education. 34: 427-453.

Kearney, M and Young, K. (2007). Classroom Use of Multimedia-Support Predict-ObserveExplain Task in a Social Contuctivist Learning Environtment. Research in Sciense Education. 34:427-453.

Liew, C. W. (1995). A predict-observe-explain teaching sequence for learning about students' understandingof heat and expansion of liquids. Australian Science Teachers Journal, 41(1), 68-72.

Liew, C. W., \& Treagust, D. F. (1998). The effectiveness of predict-observe-explain tasks in diagnosing students' understanding of science and in identifying their levels of achievement. Paper presented at the annual meeting of the American Educational Research Association, San Diego.

Nana. (2014). The Development of $\mathrm{POE}_{2}$ WE Learning Model in Physics Learning at Senior Secondary School ( Surakarta :Disertation).

Nusa Putra. (2012). Research \& Development Penelitian dan Pengembangan: Suatu Pengantar. Jakarta: Raja Gravindo Persada.

Palmer, D. (1995). The POE in the primary school: An evaluation. Research in Science Education, 25(3),323-332.

White, R \& Gustone, R. (1992). Probing understanding. London: The Falmer Press. 